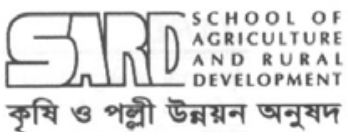

\title{
Critical Limit of Zinc for Rice in Calcareous Soils
}

\author{
M.A. RAHMAN ${ }^{*}$, M. JAHIRUDDIN ${ }^{2}$ AND M.R. ISLAM ${ }^{3}$ \\ ${ }^{1}$ Soil Science Division, Bangladesh Agricultural Research Institute, Gazipur, Bangladesh \\ ${ }^{2 \& 3}$ Department of Soil Science, Bangladesh Agricultural University, Mymensingh, Bangladesh
}

\begin{abstract}
A pot culture experiment was conducted to determine the critical limit of $\mathrm{Zn}$ for rice grown in calcareous soils collected from the High Ganges River Floodplain (AEZ 11). The soils contained $\mathrm{CaCO}_{3}$ 0.68-6.95\%, pH 7.1-7.8, organic matter 1.32-2.49\% and clay 9.0-33.0\%. The available $\mathrm{Zn}$ content of soils was estimated by three extraction methods and the amount of extraction followed the

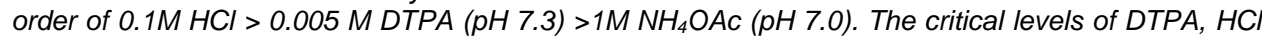
and $\mathrm{NH}_{4} \mathrm{OAc}$ extractable $\mathrm{Zn}$ were found to be $0.83,1.80$ and $0.40 \mathrm{ppm}$, respectively for rice as determined by Cate and Nelson's graphical procedure. The DTPA extractable Zn showed a positive correlation with DM yield and plant Zn content. Thus, the DTPA extraction can be regarded as a good method for determining available $\mathrm{Zn}$ status in calcareous soils.
\end{abstract}

Key words: Calcareous soil, critical limit, rice, zinc.

\section{INTRODUCTION}

Zinc deficiency is common in maize and rice, and for all crops grown in calcareous soils. This element deficiency has arisen in Bangladesh mainly due to continuous mining of soil nutrients for increase cropping intensity (180\% at present). The availability of $\mathrm{Zn}$ in the soil varies widely depending on the soil properties. The calcareous soils have low to medium extractable $\mathrm{Zn}$ content (Jahiruddin and Islam 1999). Critical limit (CL) of a nutrient in soils refers to a level below which the crops will readily respond to its application. This level varies with crops, soil, and the extractants used. Zinc application is usually made on the basis of soil fertility class, thus the crop response to added $\mathrm{Zn}$ is not always obtained. The information on $\mathrm{Zn}$ fertilizer use emanating from soil testing laboratories should be based on the critical limits of extractable $\mathrm{Zn}$ for different crops and soils. In this country, most of the cultivable land especially calcareous soils are showing Zn deficiency invariably and information in relation to zinc fertilizer management is inadequate. Therefore, the situation justifies a need to determine the critical limit of $\mathrm{Zn}$ for rice in calcareous soils in order to formulate the optimum fertilizer dose of $\mathrm{Zn}$ for rice for obtaining satisfactory yield.

\section{MATERIALS AND METHODS}

A Pot experiment with Boro rice (BRRI dhan 29) was conducted in the net house of the Department of Soil Science, Bangladesh Agricultural University (BAU), Mymensingh with 16 top soils $(0-15 \mathrm{~cm})$. The soils were collected from different locations of High Ganges River Floodplain (AEZ 11) in the Rajshahi district. The sampling sites had a wide range of land types (Table 1). There were two Zn

\footnotetext{
* Corresponding author: Scientific Officer, Soil Science Division, BARI, Gazipur 1701. E-mail: arifsoil@yahoo.com

(C) 2006 School of Agriculture and Rural Development, Bangladesh Open University, All rights reserved.
} 
treatments viz. 0 and $5 \mathrm{ppm}$ (soil basis). Each of the treatments was replicated thrice in a Completely Randomized Design (CRD) to give a total of $6(2 \times 3)$ pots for each soil. Thus the total number of plastic pots used in this study was $96(6 \times 16)$. An amount of $2.5 \mathrm{~kg}$ of each soil was weighed into a series of 6 pots and three rice seedlings were planted in each pot $A$ basal application was made with 100 ppm N, 25 ppm P, 40 ppm K and 25 ppm S in each pot to support normal plant growth. The nutrients (N, P, K, S and $\mathrm{Zn})$ were added in solution at the rate of 10 $\mathrm{ml} /$ pot through $\mathrm{CO}\left(\mathrm{NH}_{2}\right)_{2}, \mathrm{KH}_{2} \mathrm{PO}_{4}, \mathrm{KCl}, \mathrm{CaSO}_{4}, 2 \mathrm{H}_{2} \mathrm{O}$ and $\mathrm{ZnCl}_{2}$, respectively and mixed thoroughly with the soil. The soils of all pots were kept moist with addition of distilled water periodically. In all pots $50 \mathrm{mg} \mathrm{N} / \mathrm{kg}$ soil as urea in solution was applied at vegetative stage after three weeks of planting. The plants were cut at the stage of 6 weeks, washed with distilled water and dried in an oven at $65^{\circ} \mathrm{C}$ for 24 hours. The initial soil samples were analyzed for both mechanical and chemical compositions following standard methods (Page et al., 1989). Available $\mathrm{Zn}$ content of soil was determined by three extractants viz. DTPA $(0.005 \mathrm{M}), \mathrm{HCl}(0.1 \mathrm{M})$ and $\mathrm{NH}_{4} \mathrm{OAc}(1 \mathrm{M})$. The extractable $\mathrm{Zn}$ content of soil and $\mathrm{Zn}$ content of plant in the digest were determined directly by atomic absorption spectrophotometer.

Table 1. General characteristics and extractable $\mathrm{Zn}$ of the soils

\begin{tabular}{|c|c|c|c|c|c|c|c|c|}
\hline \multirow{2}{*}{$\begin{array}{c}\text { Soil } \\
\text { (location) }\end{array}$} & \multirow[t]{2}{*}{ Soil series } & \multirow{2}{*}{$\begin{array}{c}\text { Textural } \\
\text { class } \\
\text { (USDA) }\end{array}$} & \multirow[t]{2}{*}{$\mathrm{pH}$} & \multirow{2}{*}{$\begin{array}{c}\% \\
\text { organic } \\
\text { matter }\end{array}$} & \multirow{2}{*}{$\begin{array}{c}\% \\
\mathrm{CaCO}_{3}\end{array}$} & \multicolumn{3}{|c|}{ Extractable Zn (ppm) } \\
\hline & & & & & & DTPA-Zn & $\mathrm{HCl}-\mathrm{Zn}$ & $\mathrm{NH}_{4} \mathrm{OAc}-\mathrm{Zn}$ \\
\hline Domandi & Sara & Silt loam & 7.6 & 1.81 & 0.68 & 0.72 & 4.11 & 0.28 \\
\hline Shibpur & Gopalpur & Silt loam & 7.7 & 2.37 & 1.23 & 0.80 & 7.20 & 0.26 \\
\hline Bashpukuria-1 & Gopalpur & Silt loam & 7.6 & 2.01 & 0.84 & 1.24 & 1.20 & 0.61 \\
\hline Bashpukuria-2 & Ishurdi & Silt loam & 7.5 & 2.25 & 6.95 & 1.08 & 9.46 & 0.41 \\
\hline Bashpukuria-3 & Mehandiganj & Silt clay loam & 7.3 & 2.45 & 6.85 & 1.08 & 0.64 & 0.16 \\
\hline Kathalbaria-1 & Gopalpur & Silt loam & 7.7 & 2.33 & 5.75 & 0.62 & 0.81 & 0.22 \\
\hline Dhopapara & Sara & Silt loam & 7.6 & 2.29 & 5.06 & 0.72 & 0.76 & 0.28 \\
\hline Chakpolashi-1 & Sara & Silt loam & 7.7 & 1.61 & 4.89 & 0.90 & 1.38 & 0.33 \\
\hline Chakpolashi-2 & Ishurdi & Silt loam & 7.6 & 2.49 & 1.56 & 0.88 & 6.65 & 0.31 \\
\hline Laudhara & Sara & Silt loam & 7.8 & 1.24 & 1.81 & 0.90 & 1.48 & 0.34 \\
\hline Meramatpur & Gopalpur & Silt loam & 7.6 & 2.41 & 2.21 & 1.18 & 8.56 & 0.56 \\
\hline Sreekhandi & Sara & Silt loam & 7.8 & 1.32 & 4.29 & 0.86 & 4.00 & 0.27 \\
\hline Zhikra & Sara & Silt loam & 7.7 & 1.53 & 2.50 & 1.16 & 7.99 & 0.67 \\
\hline Majhigram & Ghior & Silt loam & 7.1 & 2.17 & 1.25 & 1.24 & 0.98 & 0.14 \\
\hline Baroipara & Ghior & Silt loam & 7.5 & 2.33 & 1.23 & 1.42 & 4.28 & 0.42 \\
\hline Daulatpur & Ishurdi & Silt loam & 7.7 & 1.49 & 0.88 & 0.78 & 1.90 & 0.22 \\
\hline Range & & ------ & 7.1-7.8 & $1.32-2.49$ & $0.68-6.95$ & $0.62-1.42$ & $0.64-9.46$ & $0.14-0.67$ \\
\hline Mean & & ------ & 7.6 & 2.01 & 2.00 & 0.97 & 3.84 & 0.34 \\
\hline
\end{tabular}

The critical level of soil Zn was determined by following two approaches: graphical and statistical. The graphical method was followed as per Cate and Nelson (1965). In this procedure, a scatter diagram of the relative yields (Bray's per cent yield) as Y-axis versus soil test values as Xaxis was plotted.

The statistical approach was used as developed by Waugh et al. (1973).

\section{RESULTS AND DISCUSSION}

\section{Extractable $\mathrm{Zn}$ in soils by different methods}

Results of extractable $\mathrm{Zn}$ by different methods are reported in Table 1. The amount of extractable $\mathrm{Zn}$ varied markedly depending on the soils and extractants used. The lowest amount of $\mathrm{Zn}$ was extracted by $1 \mathrm{M} \mathrm{NH}_{4} \mathrm{OAC}$ and the highest by $0.1 \mathrm{M} \mathrm{HCl}$. The amount of DTPA extractable $\mathrm{Zn}$ in different soils varied from 0.62 to $1.42 \mathrm{ppm}$ (Table 1). The DTPA extractable $\mathrm{Zn}$ was negatively correlated with soil $\mathrm{pH}\left(r=-0.511^{\star}\right)$ and was positively correlated with available $\mathrm{P}\left(r=0.749^{\star *}\right)$, exchangeable $\mathrm{K}\left(r=0.545^{\star}\right)$ and exchangeable $\mathrm{Mg}\left(r=0.514^{\star}\right)$ contents (Table 2$)$. The negative 
relationship between soil $\mathrm{Zn}$ by different extractants and soil $\mathrm{pH}$ has been observed by many workers in the past (Agarwal and Sastry 1995; Jahiruddin et al. 1992). The available Zn extracted by $0.1 \mathrm{M} \mathrm{HCl}$ in different soils ranged from 0.64 to $9.46 \mathrm{ppm}$ ((Table 1$)$. The $\mathrm{HCl}$ extractable $\mathrm{Zn}$ showed no significant relationship with any of the soil properties tested (Table 2). Such results otherwise indicate that the $\mathrm{HCl}$ extracted $\mathrm{Zn}$ also from non-exchangeable pool including $\mathrm{CaCO}_{3}$ bound $\mathrm{Zn}$. Hence due to acidic action, $\mathrm{HCl}$ extracted more $\mathrm{Zn}$ than the other extractants. The amount of $\mathrm{Zn}$ extracted by $1 \mathrm{M} \mathrm{NH}_{4} \mathrm{OAc}(\mathrm{pH} 7.0)$ ranged from 0.14 to $0.67 \mathrm{ppm}$ having a mean value of $0.34 \mathrm{ppm}$ in different soils under study (Table 1). Higher value of $\mathrm{Zn}$ by all extractants were obtained with Baroipara, Bashpukuria $(1,2)$ and Zhikra soils showing a good relationship between any pair of extractants. Such result indicates that although the ability of $\mathrm{Zn}$ extraction for this pair of extractants was not same, the trends of $\mathrm{Zn}$ displacement from soils into solution by them were similar. The best correlation $\left(r=0.502^{\star}\right)$ was found between DTPA-Zn and $\mathrm{NH}_{4} \mathrm{OAc}-\mathrm{Zn}$. The DTPA$\mathrm{Zn}$ was weakly correlated with $\mathrm{HCl}-\mathrm{Zn}\left(\mathrm{r}=0.218^{\mathrm{ns}}\right)$ and similarly the $\mathrm{HCl}-\mathrm{Zn}$ was weakly associated with $\mathrm{NH}_{4} \mathrm{OAc}-\mathrm{Zn}\left(\mathrm{r}=0.379^{\mathrm{ns}}\right)$.

Table 2. Relationship ( $r$ value) of extractable $\mathrm{Zn}$ with selected soil properties

\begin{tabular}{lccccccc}
\hline $\begin{array}{c}\text { Extractable } \\
\text { Zn }\end{array}$ & Clay & pH & OM & Avail. P & Ex. K & Ex. Ca & Ex. Mg \\
\hline \hline DTPA-Zn & $0.466^{n s}$ & $-0.511^{*}$ & $0.183^{n s}$ & $0.749^{\star *}$ & $0.545^{\star}$ & $-0.332^{\text {ns }}$ & $0.512^{\star}$ \\
$\mathrm{HCl}-Z n$ & $-0.185^{\mathrm{ns}}$ & $0.156^{\mathrm{ns}}$ & $0.188^{\mathrm{ns}}$ & $0.316^{\mathrm{ns}}$ & $0.021^{\mathrm{ns}}$ & $0.108^{\mathrm{ns}}$ & $-0.187^{\mathrm{ns}}$ \\
$\mathrm{NH}_{4} \mathrm{OAC}-\mathrm{Zn}$ & $-0.276^{\mathrm{ns}}$ & $0.30^{\mathrm{ns}}$ & $-0.110^{\mathrm{ns}}$ & $0.451^{\mathrm{ns}}$ & $-0.059^{\mathrm{ns}}$ & $-0.147^{\mathrm{ns}}$ & $-0.227^{\mathrm{ns}}$ \\
\hline
\end{tabular}

** Significant at $1 \%$ level, * Significant at $5 \%$ level, ns = not significant

\section{Dry matter yield}

Dry matter weight of rice plants in $\mathrm{Zn}$ treated pots varied from 8.91 to $26.20 \mathrm{~g} /$ pot, against 6.91 to $25.90 \mathrm{~g} / \mathrm{pot}$ in the $\mathrm{Zn}$ control pots (Table 3). Addition of $\mathrm{Zn}$ increased dry matter yield to a considerable extent in soils having low available $\mathrm{Zn}$ content (0.62 to $0.89 \mathrm{ppm}$ DTPA-Zn). The Bray's percent yield ranged from 77.6 to 99.2 depending on the soils under study (Table 3 ).

Table 3. Effect of added $\mathrm{Zn}$ on the dry matter weight and $\mathrm{Zn}$ content of rice plants at 6 weeks of growth

\begin{tabular}{|c|c|c|c|c|c|}
\hline \multirow[b]{2}{*}{ Location } & \multicolumn{3}{|c|}{ Dry matter weight (g/pot) } & \multicolumn{2}{|c|}{ Zn content (ppm) } \\
\hline & $\mathrm{Zn}^{+}$ & $\mathrm{Zn}^{-}$ & $\begin{array}{c}\% \text { Relative } \\
\text { yield }\end{array}$ & $\mathrm{Zn}^{+}$ & $\mathrm{Zn}^{-}$ \\
\hline Domandi & 22.12 & 21.96 & 99.2 & 44.7 & 30.0 \\
\hline Shibpur & 20.47 & 18.74 & 91.6 & 59.0 & 39.3 \\
\hline Bashpukuria-1 & 18.87 & 18.05 & 95.7 & 56.3 & 57.7 \\
\hline Bashpukuria-2 & 22.83 & 21.82 & 95.6 & 71.3 & 56.0 \\
\hline Bashpukuria-3 & 19.03 & 18.33 & 96.3 & 110.0 & 75.7 \\
\hline Kathalbaria-1 & 18.98 & 16.62 & 87.6 & 60.0 & 49.7 \\
\hline Dhopapara & 20.48 & 19.06 & 93.1 & 47.3 & 37.3 \\
\hline Chakpolashi-1 & 19.69 & 19.07 & 96.9 & 64.3 & 55.3 \\
\hline Chakpolashi-2 & 26.20 & 25.90 & 98.8 & 83.3 & 63.0 \\
\hline Laudhara & 18.37 & 16.71 & 91.0 & 66.0 & 53.7 \\
\hline Meramatpur & 20.21 & 19.00 & 94.0 & 57.7 & 49.3 \\
\hline Sreekhandi & 8.91 & 6.91 & 77.6 & 74.3 & 67.3 \\
\hline Zhikra & 17.26 & 17.08 & 99.0 & 69.0 & 47.7 \\
\hline Majhigram & 19.29 & 18.61 & 96.5 & 72.7 & 63.0 \\
\hline Baroipara & 23.25 & 21.96 & 94.5 & 69.0 & 47.7 \\
\hline Daulatpur & 16.40 & 16.16 & 98.6 & 105.0 & 42.5 \\
\hline Range & $8.91-26.20$ & $6.91-25.90$ & 77.6-99.2 & $44.3-110.0$ & $30.0-75.7$ \\
\hline Mean & 19.31 & 18.30 & 94.1 & 69.4 & 52.2 \\
\hline
\end{tabular}

Results are the means of 3 replications, $\mathrm{Zn}^{+}=\mathrm{Zn}$ added, $\mathrm{Zn}^{-}=\mathrm{Zn}$ not added 


\section{M.A. Rahman et al.}

The $\mathrm{Zn}$ extraction by DTPA method showed significant and positive correlation with dry matter yield and $Z n$ content $\left(r=0.551^{\star}\right.$ and $r=0.573^{\star}$ respectively) (Table 4$)$. The amount of $Z n$ extraction by $\mathrm{HCl}$ and $\mathrm{NH}_{4} \mathrm{OAc}$ did not exhibit significant relationship with $\mathrm{DM}$ yield or $\mathrm{Zn}$ uptake by plants.

Table 4. Relationship ( $r$ value) of extractable $\mathrm{Zn}$ with DM yield, $\mathrm{Zn}$ content and $\mathrm{Zn}$ uptake and relative $\mathrm{DM}$ yield of rice

\begin{tabular}{lcccc}
\hline Extractable Zn & DM yield & Zn content & Zn uptake & $\begin{array}{c}\text { Relative DM } \\
\text { yield }\end{array}$ \\
\hline \hline $0.005 \mathrm{M} \mathrm{DTPA}$ & $0.551^{*}$ & $0.573^{*}$ & $0.369^{\text {ns }}$ & $0.069^{\text {ns }}$ \\
$0.1 \mathrm{M} \mathrm{HCl}$ & $0.264^{\text {ns }}$ & $-0.159^{\text {ns }}$ & $0.082^{\text {ns }}$ & $-0.005^{\text {ns }}$ \\
$1 \mathrm{M} \mathrm{NH}_{4} \mathrm{OAC}$ & $0.099^{\text {ns }}$ & $-0.142^{\text {ns }}$ & $-0.014^{\text {ns }}$ & $0.107^{\text {ns }}$ \\
\hline
\end{tabular}

* = Significant at $5 \%$ level, $\mathrm{ns}=$ Not significant

\section{Critical level of soil available Zn}

In the graphical procedure, the critical level of DTPA extractable $\mathrm{Zn}$ for rice was found to be $0.83 \mathrm{ppm}$ and that for $\mathrm{HCl}$ and $\mathrm{NH}_{4} \mathrm{OAc}$ extraction methods appeared to be 1.8 and $0.40 \mathrm{ppm}$, respectively (Figs. 1-3). Chhibba et al. (1997) reported that both graphical and statistical methods indicated $0.76 \mathrm{ppm}$ as the critical value of $\mathrm{Zn}$ deficiency soils. The critical limits of $\mathrm{Zn}$ for DTPA, $\mathrm{HCl}$ and $\mathrm{NH}_{4} \mathrm{OAc}$ extraction methods by using statistical approach are $0.83,2.6$ and $0.26 \mathrm{ppm}$ respectively. The statistically calculated critical level (CL) of soil Zn $(0.83 \mathrm{ppm})$ for rice determined by DTPA extraction method was same as that of graphical method while the $\mathrm{CL}$ values of $\mathrm{HCl}(1.8)$ and $\mathrm{NH}_{4} \mathrm{OAc}(0.40 \mathrm{ppm})$ extractable $\mathrm{Zn}$ varied considerably between graphical and statistical methods.

The study thus indicates that DTPA is a better extractant for assessing available zinc status of calcareous soils. It is expected that the AEZ 11 soils will likely respond to $\mathrm{Zn}$ application when the soils contain less than $0.83 p p m$ DTPA extractable $Z n$.

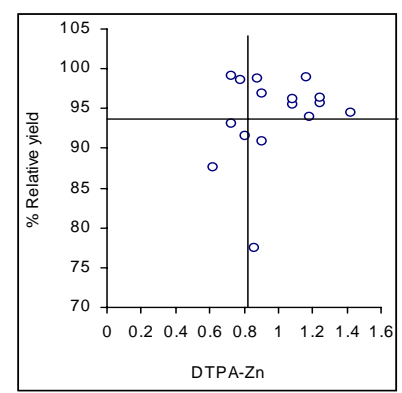

Fig. 1 Critical limit of DTPA extractable $\mathrm{Zn}$ for rice

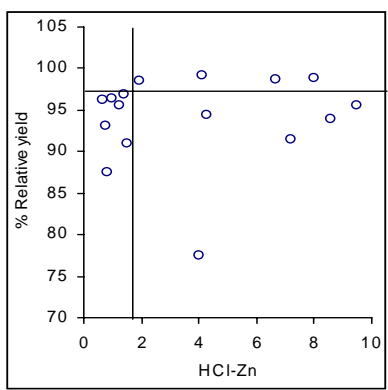

Fig. 2 Critical limit of $\mathrm{HCl}$ extractable Zn for rice

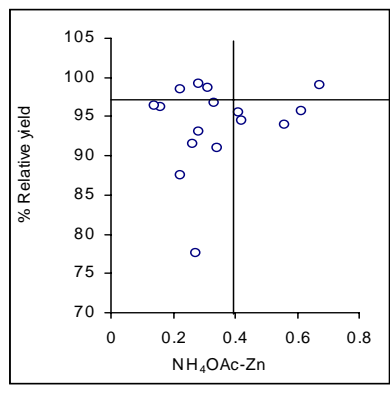

Fig. 3 Critical limit of $\mathrm{NH}_{4} \mathrm{OAc}$ extractable $\mathrm{Zn}$ for rice 


\section{LITERATURE CITED}

Agarwal, B. and Sastry, T. G. 1995. EDTA-an extraction for iron and zinc from different soils. J. Indian Soc. Soil Sci. 43(1), 126-127.

Cate, R. B. and Nelson, L. A. 1965. Tech. Bull. I. Int. Soil Testing Serv. Series. North Carolina State Univ. Releigh.

Chhibba, I. M., Nayyar, V. K. and Takkar, P. N. 1997. Critical value of zinc deficiency for predicting response of sorghum to zinc application on typic Ustipsamments. J. Indian Soc. Soil Sci. 45(1), 130-132.

Jahiruddin, M. and Islam, M. R.1999. Studies on secondary and micronutrients in soils and crops of some major AEZs of Bangladesh. Annual report 1998-1999. BARC. Farmgate, Dhaka.

Jahiruddin, M.; Chambers, B. J., Cresser, M. S. and Livesey, N. T. 1992. Effect of soil properties on the extraction of zinc. Geoderma 52, 199-208.

Page, A. I., Miller, R. H. and Keeney, D. R. 1989. "Methods of Soil Analysis". Part 2. $2^{\text {nd }}$ Ed. American Soc. Agron. Inc. Madi Wis. USA.

Waugh, D. L., Cate, J. R. B. and Nelson, L. A. 1973. International soil fertility evaluation and improvement program. Tech. Bull. No. 7. 